\title{
How Long, Narrowly Constructed Wetlands Purify Irrigation Return Water: A Case Study of Ulansuhai Lake, China
}

\author{
Xufeng Mao, ${ }^{1}$ Donghai Yuan, ${ }^{2}$ Liansheng He, ${ }^{3}$ Xiaoyan Wei, \\ Qiong Chen, ${ }^{1}$ Libo Bian, ${ }^{2}$ and Junqi $\mathrm{Li}^{2}$ \\ ${ }^{1}$ College of Life and Geography Sciences, Key Laboratory of Tibetan Plateau Environment and Resources, Ministry of Education, \\ Qinghai Normal University, Qinghai, Xining 810000, China \\ ${ }^{2}$ Key Laboratory of Urban Stormwater System and Water Environment, Ministry of Education, Beijing Climate Change Response \\ Research and Education Center, Beijing University of Civil Engineering and Architecture, Beijing 100044, China \\ ${ }^{3}$ Water Environment System Project Laboratory, Chinese Research Academy of Environmental Sciences, Beijing 100012, China
}

Correspondence should be addressed to Donghai Yuan; yuandonghai@aliyun.com and Liansheng He; heliansheng08@126.com

Received 18 September 2014; Revised 11 March 2015; Accepted 20 April 2015

Academic Editor: Jinwei Dong

Copyright (C) 2015 Xufeng Mao et al. This is an open access article distributed under the Creative Commons Attribution License, which permits unrestricted use, distribution, and reproduction in any medium, provided the original work is properly cited.

The use of constructed wetlands (CWs) in the treatment of raw wastewater in China has proved to be very successful in recent decades. However, it is not known whether surface-flow constructed wetlands can effectively purify irrigation return water. To investigate the performance of a constructed wetland in terms of meeting the goals of pollutant purification, the 8th drainage of Ulansuhai Lake was used for this study. Pollutant removal performances, as well as hydrological characteristic variations in relation to specific characteristics of plants, were investigated utilizing two years of monthly average data. The results indicated that surface-flow constructed wetlands can effectively change the physical characteristics of return water and lead to a sharp decrease in pollutant concentrations. The $1200 \mathrm{~m}$ long, narrowly constructed wetland resulted in the average reduction rates of total nitrogen (TN) and total phosphorus (TP) of up to $22.1 \%$ and $21.5 \%$, respectively. The overall purification efficient of the constructed wetland presented seasonal variations in four different monitoring periods (May, July, September, and November). Constructed wetlands with multiple types of plants exhibited higher efficiencies in pollutants removal than those with a single type of plant. The current study can provide meaningful information for the treatment of agricultural wastewater.

\section{Introduction}

Lake eutrophication has become a significant ecological environmental problem facing freshwater lakes in China [1]. High levels of nitrogen in water bodies are a crucial factor contributing to lake eutrophication [2-5]. The exogenous pollution of lakes is primarily caused by large amounts of fertilizer in the agricultural return water [6-8]. Therefore, educing exogenous pollutants has become the key measure in controlling the eutrophication of lakes.

Constructed wetlands serve as a valid treatment measure because investment and running costs are low, and maintenance and management are easy [9]. A CW is an artificial soil-plant-microbe system created as a new or restored habitat for native and migratory wildlife and for anthropogenic discharge, such as wastewater, stormwater runoff, or sewage treatment, for land reclamation after mining and other ecological disruptions [10-15]. Of the various types of CWs [16-19], such as surface- and subsurface-flow wetlands and vertical flow wetlands, each has a different technical characteristic and function [20-23]. Despite their advantages, CWs struggle to remove nutrients such as nitrogen and phosphates [24]. However, a higher pollutants removal efficiency has been demonstrated in constructed wetlands with continuous and intermittent artificial aeration [25-27].

CWs, which are designed to return irrigation water, have certain boundary conditions to meet [6]. For example, compared to general wastewater, irrigation return water flows faster and has a shorter hydraulic detention time. Whether a CW can work effectively in handling fast-flowing irrigation 
TABLE 1: Detailed information of the three segments of the CW.

\begin{tabular}{lccc}
\hline Segment & Segment I $(400 \mathrm{~m})$ & Segment II $(400 \mathrm{~m})$ & Segment III $(400 \mathrm{~m})$ \\
\hline \multirow{2}{*}{ Types of plants } & Phragmites communis & Phragmites communis & Phragmites communis \\
& Typha angustifolia & Typha angustifolia & Phragmites communis \\
Dominant plant & Iris tectorum Maxim & Phragmites communis & $30-35 / \mathrm{m}^{2}$ \\
Plant density & Phragmites communis & $30-35 / \mathrm{m}^{2}$ & $35 / \mathrm{m}^{2}$
\end{tabular}

return water remains to be seen. Vegetation types, plant density, and the landform may be the decisive factors in the success of return water treatment. To investigate the effects of CWs with irrigation return water, a long, narrow CW was constructed in a drainage system of Ulansuhai Lake in Inner Mongolia. The data of two years' worth of hydrologic and chemical characteristics of the irrigation return water were collected for an accurate assessment of the efficiency of constructed wetlands.

\section{Study Area Selection}

Ulansuhai Lake $\left(\mathrm{N} 40^{\circ} 36^{\prime}-41^{\circ} 03^{\prime}, \mathrm{E} 108^{\circ} 43^{\prime}-108^{\circ} 57^{\prime}\right)$ is located in Ulate County, Inner Mongolia, China. It covers an area of $292 \mathrm{~km}^{2}$ (Figure 1). Historically, Ulansuhai Lake has played an important role in maintaining the ecological balance of the surrounding region. However, for the past decade, it has faced severe eutrophication due to large amounts of input nutrients in the return water from farmland irrigation. Through nearly ten drainages from the upstream agricultural region, an average of $1088.59 \times 10^{3} \mathrm{~kg}$ nitrogen and $65.75 \times 10^{3} \mathrm{~kg}$ phosphor are discharged into the lake each year $[28,29]$. The lake is now facing a serious ecosystem health challenge [28, 29].

\section{Methods}

3.1. The CW and Sampling Sites. The CW analyzed for this study is situated in the 8 th drainage. The primary source of the drainage is from spring irrigation (April) and autumn irrigation (October) return water from the upstream region. The largest flowing velocity of these return flows reaches $0.3 \mathrm{~m} / \mathrm{s}$. The dimensions of the constructed wetland are $1200 \mathrm{~m}(L) \times$ $5.0 \mathrm{~m}(W)$. The substrates are primarily at a depth of $0.3 \mathrm{~m}$ in the natural sediments on the bottom with sparse submerged plants (Potamogeton pectinatus). The CW is divided into three segments, according to the dominant aquatic plants. Aquatic plants, including Phragmites communis, Typha angustifolia, and Iris tectorum Maxim, were chosen for the current study because they are a dominant species in the region. After nearly two years of cultivation, these plants were growing well in the CW. Detailed information is depicted in Table 1.

A total number of 12 sampling sites were set in the CW at $100 \mathrm{~m}$ intervals. Three parallel samples were collected weekly from each segment and stored at $-18^{\circ} \mathrm{C}$ until analysis.

3.2. Physical and Chemical Analyses. Water flow velocity (FV) was measured with a velocimeter, and the suspended solids (SS) were measured using the gravimetric method. TN concentrations were measured using the alkaline potassium persulfate digestion-UV spectrophotometric method, and TP concentrations were measured by the ammonium molybdate spectrophotometric method.

3.3. Removal Ratio and Purification Efficiency Analysis. The removal ratios (RRs) of the total $\mathrm{N}$ and $\mathrm{P}$ were calculated by (1), in which $C_{\text {in }}(\mathrm{mg} / \mathrm{L})$ is the $\mathrm{N}(\mathrm{P})$ concentration of inflows and $C_{\text {out }}(\mathrm{mg} / \mathrm{L})$ is the $\mathrm{N}(\mathrm{P})$ concentration of outflows:

$$
\mathrm{RR}=\frac{C_{\text {in }}-C_{\text {out }}}{C_{\text {in }}} \times 100 \% .
$$

To determine the removal efficiency (RE) of nutrients at different locations, (2) was developed and applied to calculate $\operatorname{RE} \mathrm{mg}(\mathrm{L} \cdot \mathrm{m})^{-1}$ :

$$
\mathrm{RE}_{j}=\left|\frac{C_{j}-C_{i}}{L}\right|,
$$

where $C_{j}$ is the nutrient concentration at site $j$; $C_{i}$ is the nutrient concentration at site $i$ (both in units of $\mathrm{mg} / \mathrm{L}$ ); and $L(\mathrm{~m})$ is the straight-line distance between site $i$ and the next site $j$.

\section{Results and Discussion}

4.1. Flow Velocity and Suspended Solids Changes in the CW. As depicted in Figure 2, there were obvious changes in the $\mathrm{FV}(\mathrm{m} / \mathrm{s})$ and SS $(\mathrm{mg} / \mathrm{L})$ after entering the CW. The average FV decreased from $0.23 \mathrm{~m} / \mathrm{s}$ to $0.09 \mathrm{~m} / \mathrm{s}$, a decline of $59.4 \%$. The return water was slowed in the $\mathrm{CW}$ by the dense aquatic plants. The biggest drop appeared in July (70.23\%), which may have been related to the vigorous growth of the aquatic plants in that month. Moreover, a low inflow velocity in July $(0.16 \mathrm{~m} / \mathrm{s})$ versus the average inflow velocity $(0.23 \mathrm{~m} / \mathrm{s})$ also proved this theory. No obvious differences were observed in the velocity drop percentages during the other three months, which averaged 55\%. Basically, the first part (before $600 \mathrm{~m}$ ) of the CW had a slightly higher drop (an average of $40 \%$ ) than that of the back part (an average of 36\%).

The average SS levels decreased from $41.0 \mathrm{mg} / \mathrm{L}$ to $21.4 \mathrm{mg} / \mathrm{L}$, a total of $48 \%$, indicating that the CW was working well in controlling water quality. The largest concentration (55 mg/L) of SS was observed in May due to the large amounts of fine solids that were brought by the return water of spring irrigation. The largest drop (59\%) appeared in July. This was attributed to the vigorous growth of the aquatic plants, as well 


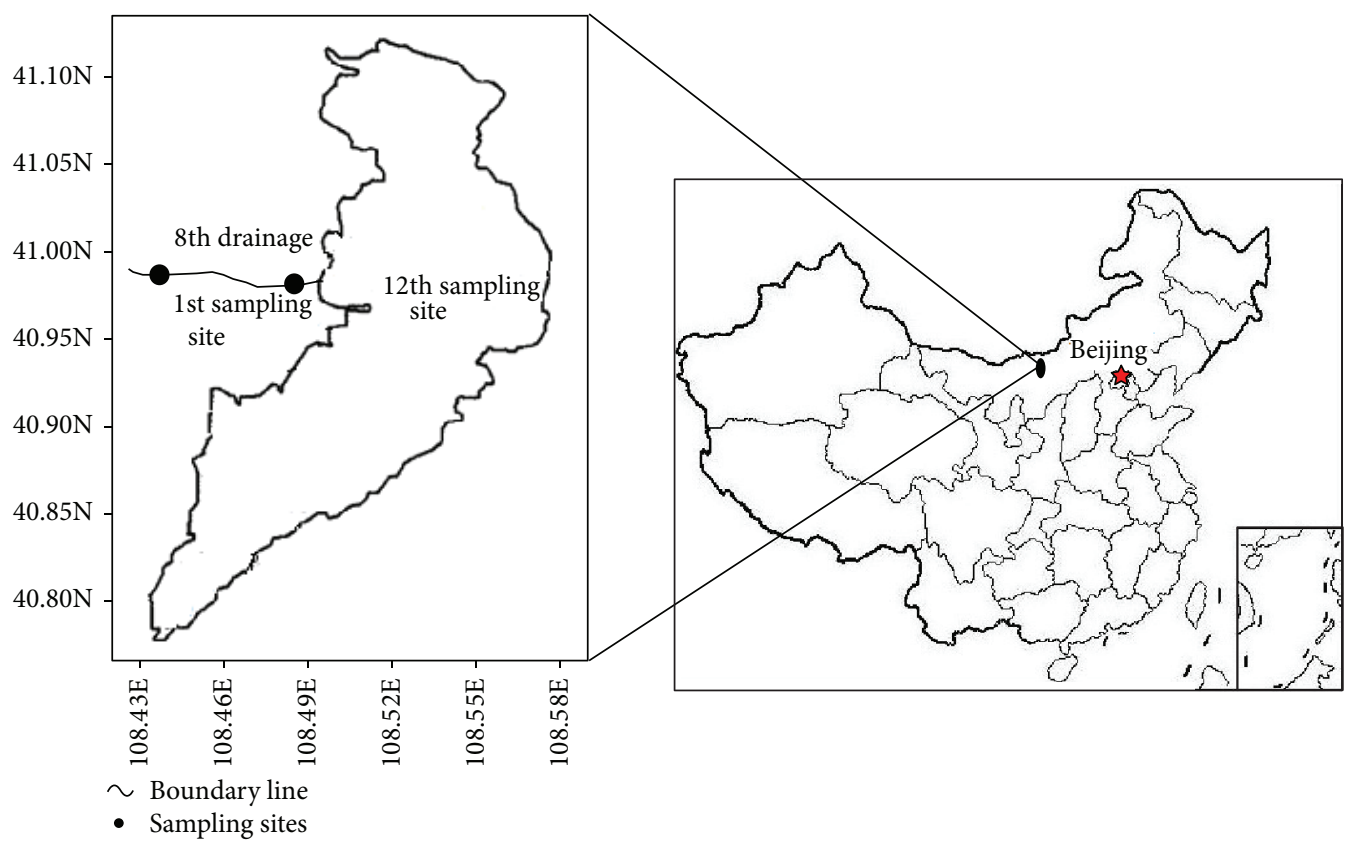

FIgURE 1: Location of the Ulansuhai Lake.
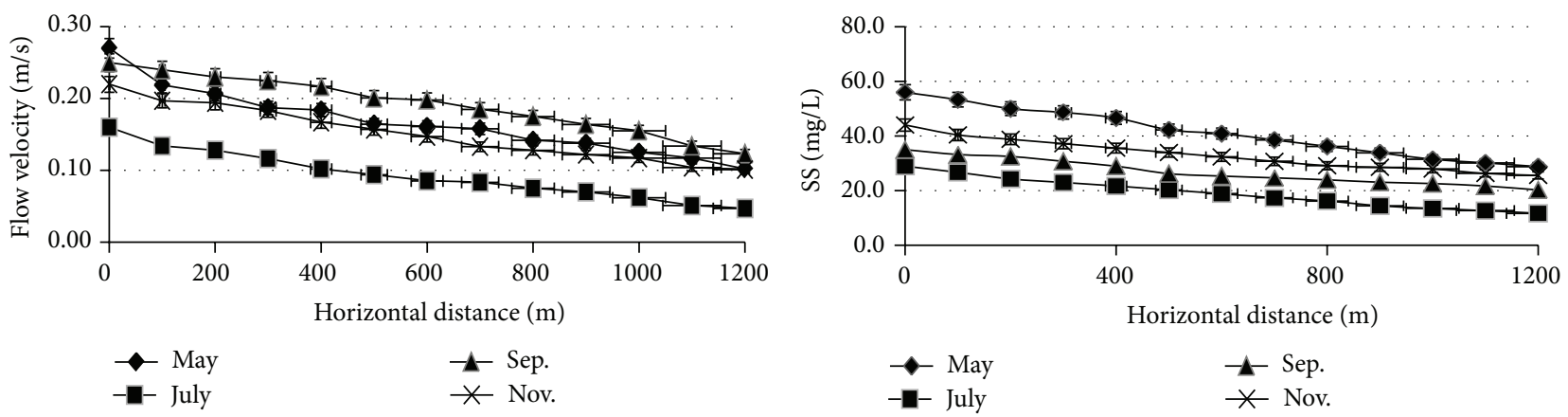

FIGURE 2: Flow velocity and suspended solids distribution in the CW.

TABLE 2: Average removal ratio of $\mathrm{N}$ and $\mathrm{P}$ in four monitoring periods.

\begin{tabular}{lccccc}
\hline & May & July & Sep. & Nov. & Average \\
\hline $\mathrm{RR}_{\mathrm{N}}$ & 0.235 & 0.282 & 0.203 & 0.164 & $22.1 \%$ \\
$\mathrm{RR}_{\mathrm{P}}$ & 0.224 & 0.313 & 0.211 & 0.113 & $21.5 \%$
\end{tabular}

as the lower initial inflow velocity in this region. The average drops in the SS level in the four periods were $48.5 \%, 59.6 \%$, $42.0 \%$, and $46.8 \%$. The lowest removal ratio of SS appeared in November, when many plants withered up. During the months of May and July, the first part (before $500 \mathrm{~m}$ ) of the CW had lower removal ratios (an average of $27.5 \%$ ) than those of the back part (an average of 34\%). Conversely, September and November showed higher removal ratios in the front part of the CW (an average of 24\%) than those of the back part (an average of 20\%). Therefore, the growth conditions of the aquatic plants are thought to be a decisive factor in the removal ratios of suspended solids.
4.2. Removal Ratios of $N$ and $P$. The average removal ratios of $\mathrm{N}$ and $\mathrm{P}$ in the four monitored periods are listed in Table 2.

The average $R_{T N}$ and $R_{T P}$ were $22.1 \%$ and $21.5 \%$, respectively, indicating the $\mathrm{CW}$ performed well in handling fast-flowing return wastewater from agricultural irrigation. The $\mathrm{RR}_{\mathrm{TN}}$ of the four monitored periods was $23.5 \%, 28.2 \%$, $20.3 \%$, and $16.4 \%$. The largest RR of TN appeared in July and the least $\mathrm{RR}$ appeared in November. The $\mathrm{RR}_{\mathrm{TP}}$ of the four periods was $22.4 \%, 31.3 \%, 21.1 \%$, and $11.3 \%$. In consideration of the temporal distribution, July had the largest RR of total $\mathrm{N}$ and total $\mathrm{P}$, which was closely related to the exuberant growth of the aquatic plants in that season. Contrarily, a peak removal ratio appeared in November, when most of the aquatic plants were in a stage of growth retardation. Compared to RV of $60 \%-80 \%$, or higher, in other constructed wetlands [30], the RV of the current study is not high: $22 \%$. However, considering the fast flow of the water, the current CW appeared to be successful in treating pollutants.

The temporal and spatial distributions of RRs in the 8th drainage are depicted in Figure 3 . The average $R_{T N}$ and 
$\mathrm{TN}$

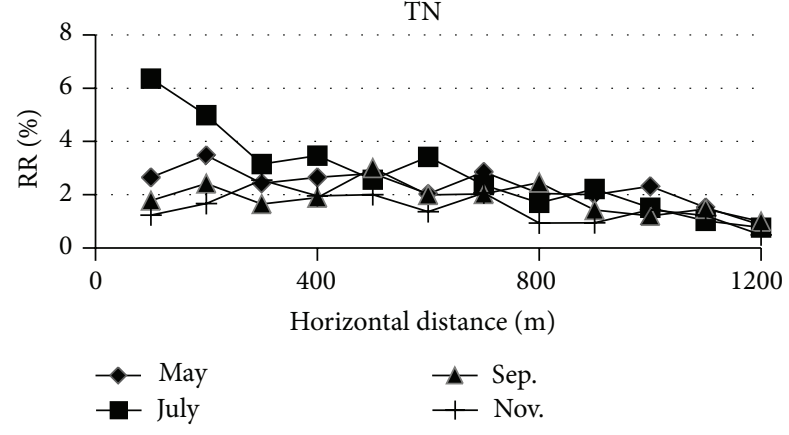

TP

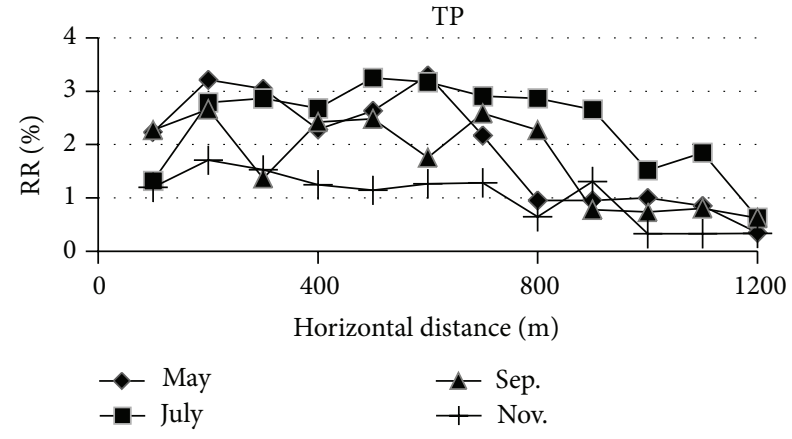

FIgURE 3: Temporal and spatial distribution of RRs in the 8th drainage.
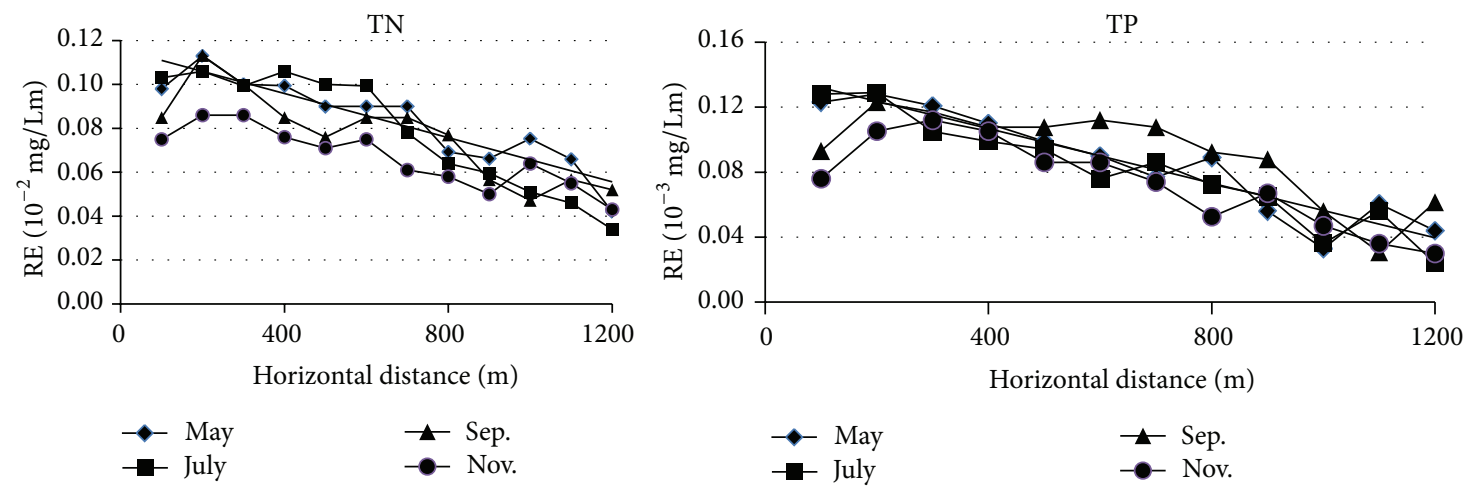

Figure 4: Temporal and spatial distribution of REs in the 8th drainage.

$\mathrm{RR}_{\mathrm{TP}}$ were $1.96 \%$ and $1.79 \%$ for each segment, respectively. In general, the $\mathrm{RR}_{\mathrm{TN}}$ and $\mathrm{RR}_{\mathrm{TP}}$ decreased with an increased length of the CW. There were no significant differences in the $\mathrm{RR}_{\mathrm{TN}}$ in the different seasons. The average RRs for the four seasons were $2.11 \%, 2.51 \%, 1.76 \%$, and $1.49 \%$, respectively. The average $\mathrm{RR}_{\mathrm{TN}}$ of each segment in July was slightly higher than the corresponding values of the other three seasons. A similar trend was observed in the temporal distribution of the average $R_{T P}$, and the average $R_{T P}$ in July was slightly higher than that of the other three seasons.

4.3. Temporal and Spatial Distribution of REs. Due to variations in water depth, vegetation, sediments, and so forth, each same-length CW presented a different level of removal efficiency. The results of the $t$-test $(P<0.01)$ also verified that there were significant differences among the different segments. The temporal and spatial distributions of the REs in the 8th drainage are depicted in Figure 4.

The average $\mathrm{RE}_{\mathrm{TN}}$ was $0.08 \times 10^{-2} \mathrm{mg}(\mathrm{L} \cdot \mathrm{m})^{-1}$ with a slight decreasing tendency. For example, the RE in the first segment was $1.2 \times 10^{-2} \mathrm{mg}(\mathrm{L} \cdot \mathrm{m})^{-1}$, which was almost triple the amount in the last segment $0.44 \times 10^{-2} \mathrm{mg}(\mathrm{L} \cdot \mathrm{m})^{-1}$. However, the largest RE appeared in the second segment. The high FV of the return water was thought to have contributed to this result. In consideration of temporal distribution of REs, July exhibited the highest average $\mathrm{RE}_{\mathrm{TN}}$ among the four monitored periods. That was in accordance with the variation law of RVs. A similar variation tendency was observed in the REs of TP. The average $\mathrm{RE}_{\mathrm{TP}}$ was 0.083 $\times 10^{-3} \mathrm{mg}(\mathrm{L} \cdot \mathrm{m})^{-1}$ with a slight decreasing tendency. The peak and valley values of $\mathrm{RE}_{\mathrm{TP}}$ appeared in July $(0.13 \times$ $\left.10^{-3} \mathrm{mg}(\mathrm{L} \cdot \mathrm{m})^{-1}\right)$ and November $\left(0.03 \times 10^{-3} \mathrm{mg}(\mathrm{L} \cdot \mathrm{m})^{-1}\right)$, respectively. Dissimilarly, the seasonal variation of the $\mathrm{RE}_{\mathrm{TP}}$ was smaller than the $\mathrm{RE}_{\mathrm{TN}}$. Generally, both regularities and complexities existed in the temporal and spatial distributions of the REs. Many factors, including flow flux, velocity, and landform, produced different influences on the experimental results.

4.4. Absorption of $N$ and $P$ by Aquatic Plants. Absorption by aquatic plants is the primary way of reducing $\mathrm{N}$ and $\mathrm{P}$ in a surface-flow CW [31]. To test the absorption efficiency of different types of aquatic plants, the average percentage concentrations (PC) of TN and TP in the leaves of each plant were analyzed. Related results are illustrated in Figure 5.

The average percentage concentration (APC) of TN in the Phragmites communis (2.46\% average) was slightly higher than the Typha angustifolia (2.08\%) and Iris tectorum Maxim $(2.19 \%)$. The seasonal variations of the $\mathrm{PC}_{\mathrm{TN}}$, in descending order, were July (3.68\%), September (2.65\%), May $(2.12 \%)$, and November $(1.39 \%)$, which was in accordance with the seasonal order of Iris tectorum Maxim. The descending order of the Typha angustifolia was slightly different: July (3.18\%), May (2.07\%), September (1.84\%), and November $(1.21 \%)$. The APC of TP in the Typha angustifolia is (3.07\%) was slightly higher than in the Phragmites communis $(2.75 \%)$ 

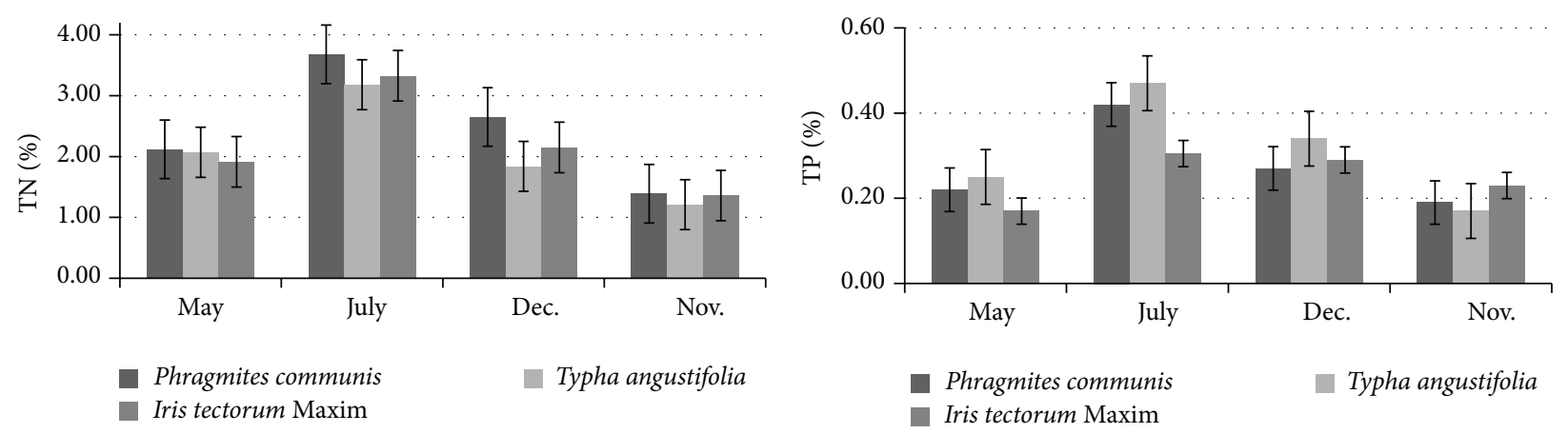

FigURE 5: Nutrient concentration in the leaves of tree types of aquatic plants.

and Iris tectorum Maxim (2.48\%). The APC-TP in July $(4.0 \%)$ was significantly higher than the other three seasons (2.5\%). Different types of plants have different capabilities of absorbing nutrients in different seasons, and further scientific research is needed to obtain more accurate conclusions.

4.5. Correlation between Related Indicators. The Pearson correlation index was used to analyze the simple correlations among five environmental indicators (Table 3).

The FV presented a strong positive correlation with TN $(a=0.953, P<0.01)$ and TP $(a=0.983, P<0.01)$, indicating the high flowing velocity has serious purification effects in CWs. Thus, a smaller drainage gradient (longer hydraulic detention time for water) contributes to a higher RR of pollutants. Additionally, the faster the FV, the higher the SS $(a=0.987, P<0.01)$. Negative correlations existed between the CW length and TN $(a=-0.956, P<0.01)$, TP $(a=-0.972, P<0.01), \mathrm{FV}(a=-0.975, P<0.01)$, and SS $(a=$ $-0.989, P<0.01$ ), indicating the current CW performs well in treating fast-flowing return water. If the surface flow of the CW could be spread to the entire drainage, better purification results would be achieved. Due to the limited data, more quantitative conclusions with respect to the relations among different indicators cannot be provided. For example, if the plant density of each segment for each month were provided, then it could be quantitatively concluded whether the density of the aquatic plants or the type of aquatic plant was the decisive factor of the RR of SS. More experimental data will be collected in future work.

\section{Conclusion}

In the current study, a $1200 \mathrm{~m}$ long CW was constructed to detect the effectiveness of surface-flow CWs in the treatment of fast-flowing water in Ulansuhai Lake in Northern China. With monitoring and experimental data, the performances of surface-flow CWs were investigated. A preliminary conclusion was that the current CW effectively reduces the nutrient concentrations of the irrigation return water, even with a relatively high water flow velocity. Plant types and the CW length obviously affected the removal ratio of nutrients, and different types of plants had different capabilities of absorbing various nutrients. Moreover, the performance of
TABLE 3: Correlation analysis among five environmental indicators.

\begin{tabular}{lccccc}
\hline & TN & TP & FV & SS & CW length \\
\hline TN & 1 & $.970^{* *}$ & $.953^{* *}$ & $.954^{* *}$ & $-.956^{* *}$ \\
TP & $.970^{* *}$ & 1 & $.983^{* *}$ & $.988^{* *}$ & $-.972^{* *}$ \\
FV & $.953^{* *}$ & $.983^{* *}$ & 1 & $.987^{* *}$ & $-.975^{* *}$ \\
SS & $.954^{* *}$ & $.988^{* *}$ & $.987^{* *}$ & 1 & $-.989^{* *}$ \\
CW length & $-.956^{* *}$ & $-.972^{* *}$ & $-.975^{* *}$ & $-.989^{* *}$ & 1 \\
\hline
\end{tabular}

${ }^{* * *}$ With a significance level of 0.01 .

the CW fluctuated with the seasonal fluctuations of aquatic plants. Overall, there were strong positive correlations among the TN, TP, FV, and SS, suggesting these indicators present similar variation trends in CWs. The length of the CW was an important factor in the RR of TN, TP, and SS. Moreover, plant density had a significant effect on the RE of various pollutants.

A limitation of the current study was the absence of daily, or even hourly, monitoring data. More accurate conclusions can be drawn only after a longer test and operation period. Future work should focus on plant configurations, plant density, and substrate construction in this field. The present study exhibits the great potential of CWs in dealing with agricultural wastewater.

\section{Conflict of Interests}

The authors declare no conflict of interests.

\section{Acknowledgments}

This work is supported by National Natural Science Foundation of China (no. 51409144, 51209003, and 51478026), the National Water Pollution Control and Management Technology Major Project (no. 2010ZX07320-002 and 2011ZX07301004), and key projects in the National Science \& Technology Pillar Program (no. 2012BAJ21B08).

\section{References}

[1] B. Q. Qin, G. Gao, G. Zhu et al., "Lake eutrophication and its ecosystem response," Chinese Science Bulletin, vol. 58, no. 9, pp. 961-970, 2013. 
[2] J. Vymazal, "Constructed wetlands for wastewater treatment: five decades of experience," Environmental Science and Technology, vol. 45, no. 1, pp. 61-69, 2011.

[3] E. M. Seeger, U. Maier, P. Grathwohl, P. Kuschk, and M. Kaestner, "Performance evaluation of different horizontal subsurface flow wetland types by characterization of flow behavior, mass removal and depth-dependent contaminant load," Water Research, vol. 47, no. 2, pp. 769-780, 2013.

[4] D. F. Xu, Y. X. Li, A. Howard, and Y. Guan, "Effect of earth worm Eisenia fetida and wetland plants on nitrification and denitrification potentials in vertical flow constructed wetland," Chemosphere, vol. 92, no. 2, pp. 201-206, 2013.

[5] Y. H. Wang, X. S. Song, Y. Ding, R. Niu, X. Zhao, and D. Yan, "The impact of influent mode on nitrogen removal in horizontal subsurface flow constructed wetlands: a simple analysis of hydraulic efficiency and nutrient distribution," Ecological Engineering, vol. 60, pp. 271-275, 2013.

[6] B. C. Braskerud, "Factors affecting nitrogen retention in small constructed wetlands treating agricultural non-point source pollution," Ecological Engineering, vol. 18, no. 3, pp. 351-370, 2002.

[7] F. J. Díaz, A. T. O’Geen, and R. A. Dahlgren, "Agricultural pollutant removal by constructed wetlands: implications for water management and design," Agricultural Water Management, vol. 104, pp. 171-183, 2012.

[8] A. Sharpley and X. Y. Wang, "Managing agricultural phosphorus for water quality: lessons from the USA and China," Journal of Environmental Sciences, vol. 26, no. 9, pp. 1770-1782, 2014.

[9] J. Vymazal, "Removal of nutrients in various types of constructed wetlands. Contaminants in natural and constructed wetlands: pollutant dynamics and control-wetland pollution and control special issue," Science of the Total Environment, vol. 380, no. 1-3, pp. 48-65, 2007.

[10] D. J. Spieles and W. J. Mitsch, "The effects of season and hydrologic and chemical loading on nitrate retention in constructed wetlands: a comparison of low- and high-nutrient riverine systems," Ecological Engineering, vol. 14, no. 1-2, pp. 77-91, 1999.

[11] M. Scholz, P. Höhn, and R. Minall, "Mature experimental constructed wet-lands treating urban water receiving high metal loads," Biotechnology Progress, vol. 18, no. 6, pp. 1257-1264, 2002.

[12] D. P. Mungasavalli and T. Viraraghavan, "Constructed wetlands for stormwater management: a review," Fresenius Environmental Bulletin, vol. 15, no. 11, pp. 1363-1372, 2006.

[13] Y. H. Zhang, H. F. Jia, Y. J. Yao, and X. G. Chen, "Evaluating the evolution of the old urban river system of the plain river network in Southern Jiangsu Province, China," Journal of Food, Agriculture and Environment, vol. 11, no. 3-4, pp. 2556-2560, 2013.

[14] W. J. Mitsch, "Wetland creation and restoration," in Encyclopedia of Biodiversity, S. Levin, Ed., Elsevier, Amsterdam, The Netherlands, 2nd edition, 2013.

[15] H. F. Jia, Z. X. Sun, and G. H. Li, "A four-stage constructed wetland system for treating polluted water from an urban river," Ecological Engineering, vol. 71, pp. 48-55, 2014.

[16] H. Wang and J. W. Jawitz, "Hydraulic analysis of cell-network treatment wetlands," Journal of Hydrology, vol. 330, no. 3-4, pp. 721-734, 2006.

[17] Y. J. Zhao, B. Liu, W. G. Zhang, Y. Ouyang, and S. Q. An, "Performance of pilot-scale vertical-flow constructed wetlands in responding to variation in influent $\mathrm{C} / \mathrm{N}$ ratios of simulated urban sewage," Bioresource Technology, vol. 101, no. 6, pp. 16931700, 2010.

[18] C. Ávila, M. Garfí, and J. García, “Three-stage hybrid constructed wetland system for wastewater treatment and reuse in warm climate regions," Ecological Engineering, vol. 61, pp. 4349, 2013.

[19] J. Vymazal and T. Březinová, "Long term treatment performance of constructed wetlands for wastewater treatment in mountain areas: four case studies from the Czech Republic," Ecological Engineering, vol. 71, pp. 578-583, 2014.

[20] M. M. Spacil, J. H. Rodgers Jr., J. W. Castle, and W. Y. Chao, "Performance of a pilot-scale constructed wetland treatment system for selenium, arsenic, and low-molecular-weight organics in simulated fresh produced water," Environmental Geosciences, vol. 18, no. 3, pp. 145-156, 2011.

[21] N. Badhe, S. Saha, R. Biswas, and T. Nandy, "Role of algal biofilm in improving the performance of free surface, up-flow constructed wetland," Bioresource Technology, vol. 169, pp. 596604, 2014.

[22] J. Vymazal and L. Kropfelova, Wastewater Treatment in Constructed Wetlands with Horizontal Subsurface Flow, vol. 14 of Series of Environmental Pollution, Springer, Berlin, Germany, 2008.

[23] E. Ranieri, A. Gorgoglionea, and A. Solimeno, "A comparison between model andexperimental hydraulic performances in a pilot-scale horizontal subsurface flow constructed wetland," Ecological Engineering, vol. 60, pp. 45-49, 2013.

[24] J. Vymazal, “The use of hybrid constructed wetlands for wastewater treatment with special attention to nitrogen removal: a review of a recent development," Water Research, vol. 47, no. 14, pp. 4795-4811, 2013.

[25] J. L. Fan, W. G. Wang, B. Zhang et al., "Nitrogen removal in intermittently aerated vertical flow constructed wetlands: impact of influent COD/N ratios," Bioresource Technology, vol. 143, pp. 461-466, 2013.

[26] P. Foladori, A. R. C. Ortigara, J. Ruaben, and G. Andreottola, "Influence of high organic loads during the summer period on the performance of hybrid constructed wetlands (VSSF + HSSF) treating domestic wastewater in the Alps region," Water Science and Technology, vol. 65, no. 5, pp. 890-897, 2012.

[27] M. Tao, F. He, D. Xu, M. Li, and Z. Wu, "How artificial aeration improved sewage treatment of an integrated verticalflow constructed wetland," Polish Journal of Environmental Studies, vol. 19, no. 1, pp. 183-191, 2010.

[28] X. F. Mao, X. W. Wang, Q. Chen, and X. A. Yin, "A PSR-modelbased regional health assessment of the lake Ulansuhai," Polish Journal of Environmental Studies, vol. 23, no. 6, pp. 2093-2012, 2014.

[29] X. Mao, C. Wang, X. Wei, and Q. Chen, "The distribution of Chlorophyll-a and its' correlation with related indicators in the Ulansuhai Lake, China," Journal of Environmental Accounting and Management, vol. 2, no. 2, pp. 123-131, 2014.

[30] X. X. Ju, S. Wu, X. Huang, Y. Zhang, and R. Dong, "How the novel integration of electrolysis in tidal flow constructed wetlands intensifies nutrient removal and odor control," Bioresource Technology, vol. 169, pp. 605-613, 2014.

[31] C. H. House, S. W. Broome, and M. T. Hoover, "Treatment of nitrogen and phosphorus by a constructed upland-wetland wastewater treatment system," Water Science \& Technology, vol. 29, no. 4, pp. 177-184, 1994. 

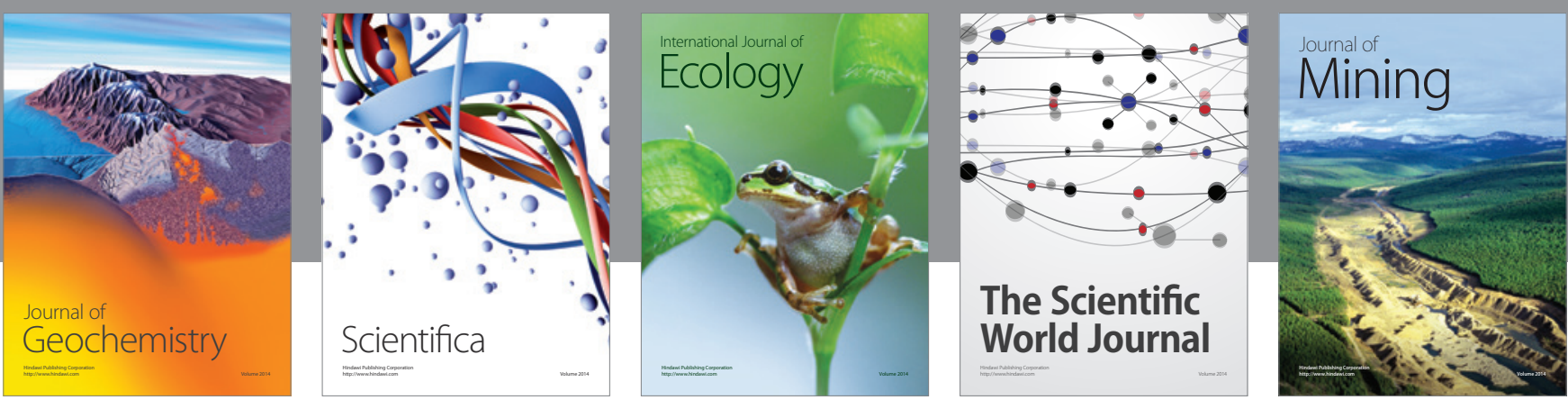

The Scientific World Journal
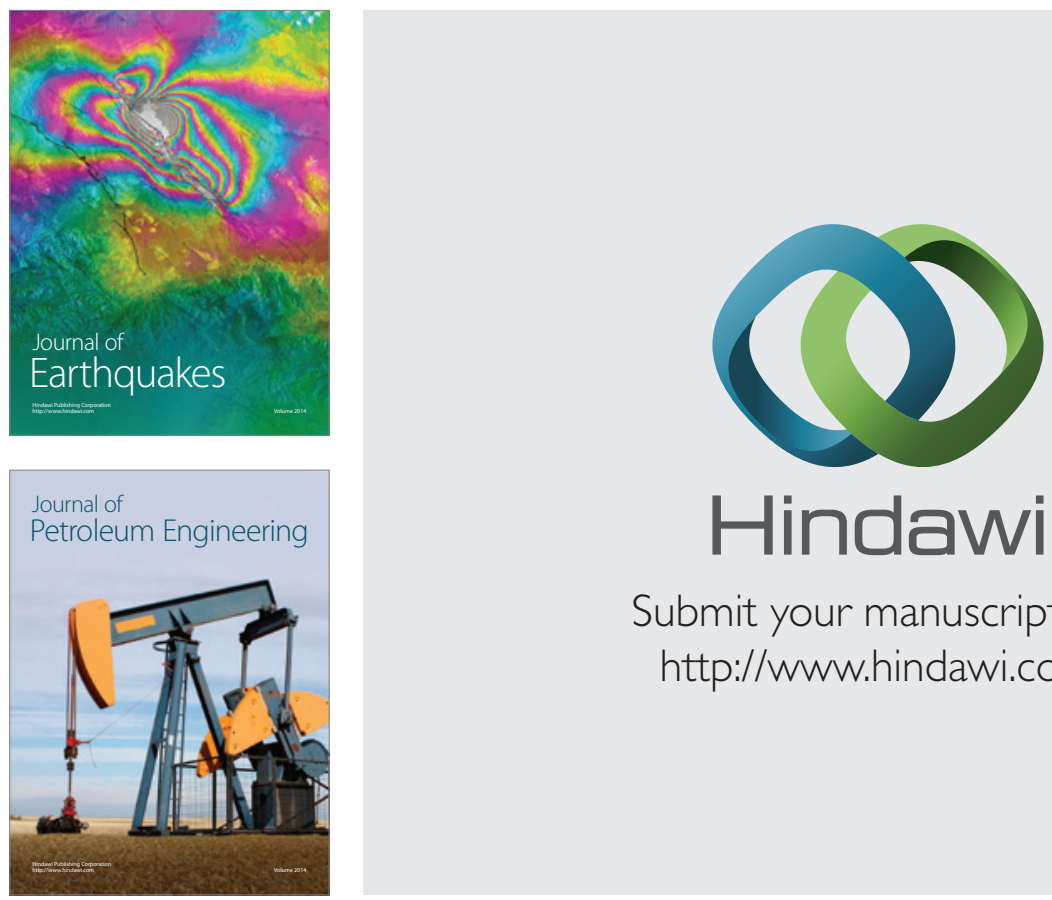

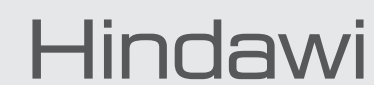

Submit your manuscripts at

http://www.hindawi.com
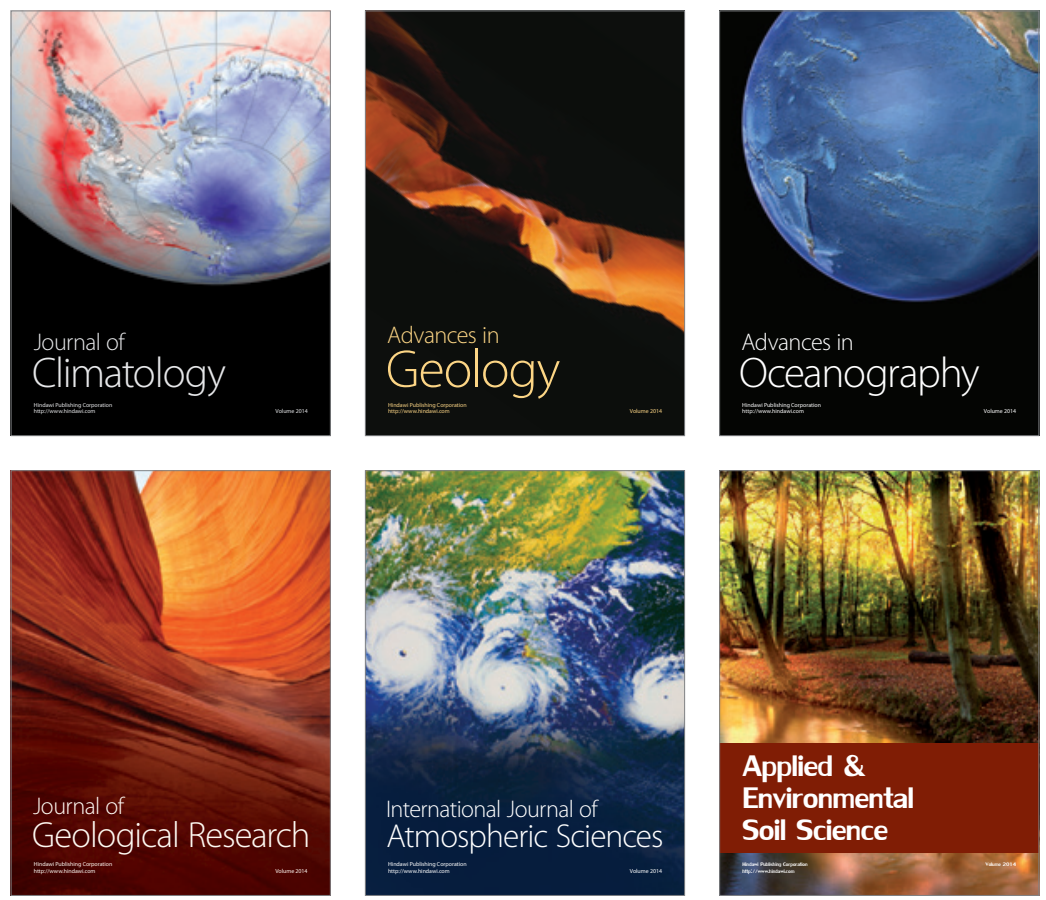
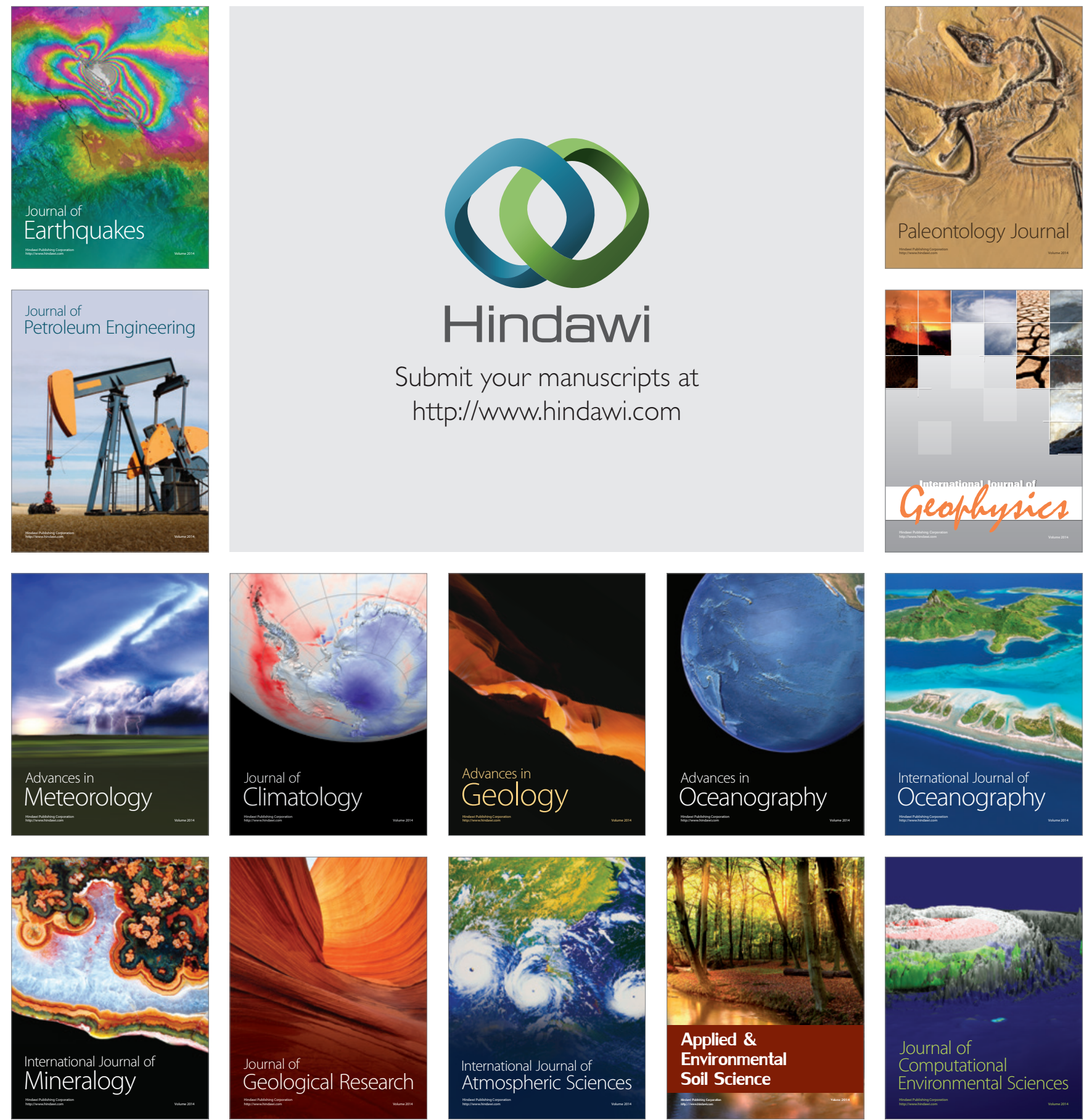